\title{
Damla Sulama Desteklemelerinin Üreticiler Tarafından Değerlendirilmesi: Edirne İli Örneği
}

\author{
Başak Aydın* $\quad$ Ozan Öztürk $\quad$ Erol Özkan $\quad$ Selçuk Özer Ülviye Çebi
}

Atatürk Toprak Su ve Tarımsal Meteoroloji Araştırma Enstitüsü Müdürlüğü, Kırklareli

* Sorumlu yazar e-posta: basakaydin_1974@yahoo.com

Geliş Tarihi: 03.04.2019

Kabul Tarihi: 14.06.2019

\section{Öz}

Bu çalışmanın amacı, Edirne ilinde damla sulama desteği alan üreticilerin damla sulama desteklemeleri programının başarı durumu, kullanımı, yasal ve ekonomik yapısı ile ilgili görüşlerinin analiz edilmesidir. Tam sayım yöntemine göre, 2012-2017 yılları arasında damla sulama desteğinden yararlanan 41 üreticinin tamamıla anket çalışması yapılmıştır. Üreticilerin damla sulama desteklemeleri hakkındaki yargılarının değerlendirilmesinde faktör analizinden yararlanılmıştır. Elde edilen faktör yükleri ile birlikte üreticilerin verdikleri cevaplar birlikte kümeleme analizine tabi tutulmuştur. Üreticilerin damla sulama desteklemesinin başarısı ve amacına ulaşması yönündeki düşünceleri ile ilgili olarak başlangıçta yer alan 15 değişken 4 faktöre indirgenmiştir. $\mathrm{Bu}$ faktörler, "Ekipmanlardan Memnuniyet”, "Desteğin Etkinliğinin Arttırılması", "Destek Uygulama Aşamalarından Memnuniyet" ve "Desteğin Bölgeye Katkısı” olarak isimlendirilmiştir. Üreticilerin proje hazırlama aşamasında karşılaştıkları problemler ile ilgili olarak başlangıçta yer alan 13 değişken 3 faktöre indirgenmiştir. Bu faktörler, "Proje Danışmanı İle İlgili Sorunlar", "Bürokratik İşlemlerle İlgili Sorunlar" ve "Başvuru İşlemleri İle İlgili Sorunlar" olarak adlandırılmıştır. Üreticilerin desteklemenin yasal yapısı yönündeki düşünceleri ile ilgili olarak başlangıçta yer alan 8 değişken 3 faktöre indirgenmiş olup bu faktörler, "Bürokratik İşlemlerin Azaltılması", "Düzenleme ve Teknik Destek" ve "Destekleme Yasası Hakkında Görüşler" olarak tanımlanmıştır. Damla sulama desteği üreticiler tarafından memnuniyeti yüksek, devam etmesi istenen bir destekleme aracı olarak kabul edilmektedir.

Anahtar Kelimeler: Damla Sulama, Destek, Faktör Analizi, Kırsal Kalkınma

\section{Evaluation of Drip Irrigation Subsidies by the Farmers: Case of Edirne Province} Abstract

The aim of this study was to analyze the opinions of the farmers related with the success, use, legal and economic structure of drip irrigation subsidies in Edirne province. Total of 41 producers who utilized from drip irrigation subsidies between 2012-2017 years in Edirne province participated in the survey. It was utilized from factor analysis in order to determine the opinions of the farmers about drip irrigation subsidies. The responses of the farmers with the factor loadings were subjected to cluster analysis. The 15 variables related with the opinions of the farmers about the success of drip irrigation subsidies were degraded to 4 factors. These factors were named as "Satisfaction from the Equipment", "Increasing the Efficiency of the Subsidy", "Satisfaction from Subsidy Application Stages" and "Contribution of the Subsidy to the Region". The 13 variables about the problems during project preparing stage was degraded to 3 factors. These factors were named as "Problems related with the Project Advisor", "Problems related with Bureaucratic Procedures" and "Problems related with Application Procedures". The 8 variables related with the opinions of the farmers about the legal structure of the subsidy were degraded to 3 factors and these factors were named as "Decreasing the Bureaucratic Procedures", "Regulation and Technical Support" and "Opinions about the Subsidy Law". Drip irrigation subsidies were accepted by the farmers as a high satisfied support tool which was desired to continue.

Keywords: Drip Irrigation, Subsidy, Factor Analysis, Rural Development

\section{Giriş}

Dünyanın artan gıda gereksinimini karşılayan ve diğer sektörlere hammadde temin eden, istihdam olanakları yaratan tarım sektörü, sosyal ve ekonomik boyutları ile sürdürülebilir kalkınmanın temel dinamiklerinden biri olma özelliğini korumaktadır. Tarım sektörünün genel istihdam içindeki payının halen yüksek olması, bu sektörün önemini daha da artırmaktadır. 
Türkiye'de tarım sektöründe faaliyet gösteren işgücünün önemi, tarımın sanayi ile bütünleşme derecesinin artmasıyla beraber kendini daha fazla göstermeye başlamıştır. Toplam üretimin işgücüne bölünmesiyle ölçülen emek verimliliği sektörde düşük seviyededir. Üretim faktörlerinin hangi oranda kullanılacağını belirleyen teknoloji seviyesi de Türkiye'de tarım sektöründe göreceli olarak düşük seviyededir. Dolayısıyla, düşük teknoloji seviyesi etkin işgücü seviyesini sektörde aşağı çekmektedir. Böyle bir ortamda tarımsal desteklerin kırsal kalkınmaya aktarılması teknolojinin teşviki açısından önem taşımaktadır (Şahin, 2008).

Kırsal kalkınma, en genel tanımıyla kırsal alanda yaşayan fertlerin ekonomik ve sosyal refahı ile yaşam kalitesini artırma sürecidir. Türkiye'de kırsal kalkınma, gerek politika tasarımı, gerekse uygulamalar bakımından sektörel ve mekânsal boyutlarının birlikte ele alındığı yapısal bir politika olarak benimsenmiștir (TCRG, 2015).

Kırsal kalkınma yatırımlarının desteklenmesi programı, kırsal alanda ekonomik ve sosyal gelişmeyi sağlamak için gerçek ve tüzel kişilerin ekonomik faaliyetlerine yönelik yapacakları yatırımlar ile basınçlı sulama sistemleri konularında yapılacak olan öz sermayeye dayalı projeli yatırımların teşvik edilmesi amacıyla hibe desteği verilmesini sağlayan kırsal kalkınma programıdır (Anonim, 2010). Kırsal kalkınma yatırımlarının desteklenmesi programı, ulusal tarım stratejisi çerçevesinde uygulamaya konulmuştur.

Kırsal kalkınma yatırımlarının desteklenmesi programı kapsamında Makine ve Ekipman Alımlarının Desteklenmesi Programı, kırsal alanda belirlenen bazı tarımsal makine ve ekipman alımlarına yönelik yapılacak harcamaları belirli oranlarda hibe olarak finansmanı yoluyla desteklemeyi hedeflemiştir. 2016 yılından sonra bu kapsamda verilen desteklemeler, Kırsal Kalkınma Destekleri Kapsamında Bireysel Sulama Sistemlerinin Desteklenmesi adı altında verilmeye başlanmış olup, yedi adet yatırım konusunu kapsamaktadır.

Tarımsal desteklemeler programlarının başarısı ve etkisinin belirlenmesine yönelik bazı çalışmalar yapılmıştır. Frandsen ve ark. (2002), AB'deki bağımsız yerel desteklemelerin ve doğrudan gelir desteğinin $\mathrm{AB}$ üyeleri üzerinde ve üye olmayan bölgeler üzerindeki etkilerini, Beycan (2009), kırsal kalkınma yatırımlarının desteklenmesi programı kapsamında proje hazırlama ve değerlendirme kriterlerini, Goeb (2011), silajlık mısıra verilen devlet desteklerinin Zambia'daki küçük pamuk üreticileri üzerine etkilerini, Taşçığlu (2011) Batı Akdeniz Bölgesinde kırsal kalkınma yatırımlarının desteklenmesi programının etkilerini, Gürkan (2012), Türkiye'de uygulanan güncel tarımsal destekleme politikaları çerçevesinde, Kahramanmaraş ilindeki uygulamaları, Demirbük (2013) Sivas ilinde kırsal kalkınma yatırımlarının desteklenmesi programının amaçlarını, Altuntop (2014) Mersin ilinde Makine Ekipman Alımlarının Desteklenmesi Programının sürdürülebilirliği ve tarım makineleri imalat sanayi üzerindeki etkilerini, Çobanoğlu ve ark. (2014) Türkiye genelinde tarıma dayalı yatırımların desteklenmesi ve makine ekipman alımlarının desteklenmesi programlarının etkilerini, Demircioğlu ve Çakmak (2016), Ziraat Bankasının basınçlı sulama destek sistemini incelemişlerdir.

Ülkemizde son yıllarda, sulanan tarım alanlarının genişletilmesi ve mevcut su kaynaklarının daha rasyonel kullanımı daha fazla önem kazanmaya başlamıştır. Bu sebeple de su kullanım etkinliğini artıran basınçlı sulama sistemleri yaygın olarak kullanılmaya başlanmıştır. Basınçlı sulama sistemlerinden damla sulama yöntemi, suyun kıt olduğu koşullarda, topoğrafyası bozuk alanlarda, su alma hızı yüksek topraklarda ve özellikle ekonomik değeri yüksek, topraktaki nem eksikliğine duyarlı bitkilerin sulanmasında kullanılabilecek en uygun sulama yöntemlerinden biridir (Ayran, 2009). Damla sulama yönteminin diğer yöntemlere kıyasla en önemli avantajlarından biri suyun araziye eşit olarak dağılımının sağlanabilmesidir (Çamoğlu ve ark. 2018).

Ülkemizde çeşitli desteklemeler sayesinde damla sulama sistemleri artış göstermiştir. $\mathrm{Bu}$ desteklemelerin etkinliğinin araştırılması, çiftçi görüşlerinin alınması yapılan desteklemelerin yararlılığını anlayabilmek ve gelecek desteklemelere yön verebilmek açısından önemlidir. Bu çalışma, Edirne ilinde damla sulama desteği alan tarım işletmelerini kapsamaktadır. Üreticilerin kırsal kalkınma destekleri kapsamında damla sulama desteği programının başarı durumu, kullanımı, yasal ve ekonomik yapısı ile ilgili görüşleri analiz edilmiştir. 


\section{Materyal ve Yöntem \\ Materyal}

Çalışmanın ana materyali Edirne ilinde damla sulama desteklemesinden yararlanan üreticilerle yapılan anket çalışmalarından oluşmaktadır. Ayrıca, araştırma konusuyla ilgili olarak yapılan yerli ve yabancı çalışmalardan da yararlanılmıştır.

\section{Yöntem}

Edirne ilinde tam sayım yöntemine göre, 2012-2017 yılları arasında damla sulama desteğinden yararlanan 41 üreticinin tamamına anket çalışması uygulanmıştır.

Verilerin analizinde ortalama, standart sapma gibi tanımlayıcı istatistikler kullanılmıştır. Üreticilerin desteklemelerin başarısı, proje hazırlama aşamasında karşılaştıkları sorunlar ve desteklemelerin yasal yapısı ile ilgili düşünceleri 5'li likert ölçeği ile (1.kesinlikle katılmıyorum, 2.katılmıyorum, 3.kararsızım, 4.katılıyorum, 5.kesinlikle katılıyorum) değerlendirilmiştir. Üreticilerin damla sulama desteklemeleri hakkındaki yargılarının değerlendirilmesinde faktör analizinden yararlanılmıştır. Faktör analizi, birbirleriyle ilişkili çok sayıda değişkeni az sayıda, anlamlı ve birbirinden bağımsız faktörler haline getiren ve yaygın olarak kullanılan çok değişkenli istatistik analizlerden biridir (Kleimbaum ve ark. 1998).

Faktör analizi dört temel aşamada gerçekleştirilmektedir. Önce verilerin faktör analizi için uygunluğunun değerlendirilmesi, faktörlerin elde edilmesi, faktörlerin rotasyonu ve faktörlerin isimlendirilmesidir. Veri setinin uygun olup olmadığını değerlendirmek amacıyla üç yöntem kullanılmaktadır. Bunlar korelasyon matrisinin oluşturulması, Kaiser-Meyer-Olkin (KMO) ve Bartlett testleridir (Akgül ve Çevik, 2003).

Değişkenler arasındaki ilişkinin bir diğer göstergesi kısmi korelasyon katsayısıdır. KaiserMeyer-Olkin (KMO) testi gözlenen korelasyon katsayılarının büyüklüğünü karşılaştıran bir indekstir. KMO değeri; 0,90 üzerinde ise mükemmel, 0,80-0,90 arasında ise çok iyi, 0,70-0,80 arasında ise iyi, 0,60-0,70 arasinda ise orta, 0,50-0,60 arasında ise zayıf ve 0,50'nin altında ise kabul edilemez olarak nitelendirilmektedir (Sharma, 1996).

Bartlett Testi (Bartlett Test of Sphericity), korelasyon matrisinde değişkenlerin en azından bir kısmı arasında yüksek oranlı korelasyonlar olduğu olasılığını test eder. Analize devam edilebilmesi için "Korelasyon matrisi birim matristir" sıfır hipotezinin reddedilmesi gerekir. Eğer sıfır hipotezi reddedilirse, değişkenler arasında yüksek korelasyon olduğu, yani veri setinin faktör analizi için uygun olduğu belirlenir (Hair ve ark. 1998). Faktör sayısının belirlenmesinde en çok özdeğere göre ve scree test grafiği kullanılır. Özdeğere (Eigenvalues) göre belirlemede, özdeğeri 1'den büyük olan faktörler türetilmektedir (Mucuk, 1978).

Elde edilen faktör yükleri ile birlikte üreticilerin verdikleri cevaplar kümeleme analizine tabi tutulmuştur. Kümeleme analizinin amacı, birey ya da nesnelerin temel özelliklerini dikkate alarak onları gruplandırmaktır. Kümeleme analizi, araştırmada gözlenen bireylerin ya da nesnelerin ölçülen tüm değişkenler üzerindeki değerlerini hesaplayarak ortaya çıkacak kümelere veya gruplara odaklanmaktadır (Kalayc1, 2009).

Çalışmada elde edilen veriler öncelikle hiyerarşik kümeleme yöntemiyle analiz edilmiş olup üç kümeye ayrılmıştır. Daha sonra hiyerarşik olmayan kümeleme yöntemlerinden k-ortalamalar kümesi yöntemiyle üç küme olarak analize tabi tutulmuştur.

K-ortalamalar yöntemine göre, küme sayısı, en az iki ve en fazla gözlem sayısına eşit ya da daha az olacak şekilde belirlenir. K-ortalama yönteminin amacı, gözlemleri, sayısı araştırıcı tarafından belirlenen kümelere sinıflamaktır (Alpar, 2011).

\section{Bulgular ve Tartışma}

\section{Üreticilerin desteklemelerin bașarısı ve amacına ulașması yönündeki düșünceleri}

Üreticilerin desteklemelerin başarısı ve amacına ulaşması ile ilgili en önemli gördükleri ve katıldıkları düşünceler desteğin devam etmesi, desteğin konu itibariyle yaygınlaştırılması ve destek miktarının arttırılmasıdır. Bunun yanında üreticilerin çevrelerini destekten yararlanmaları için teşvik edecekleri, desteğin bölge ekonomisine katkı sağladığı, desteğin bölgede ekonomik faaliyet çeşitliliğinin artmasını sağladığı ve destek ile ekipman almakla faydalı bir iş yaptıkları görüşlerine de katıldıkları görülmektedir. Destek ile alınan ekipmanın kalitesinin yeterli seviyede olduğu ve 
ekipmanın satış sonrası servis hizmetlerinin yeterli düzeyde olduğu yönündeki yargıların da üreticiler tarafından benimsendiği görülmektedir. Üreticilerin destek için verilen yatırım süresinin yeterliliği ve destekleme hakkındaki yeterli tanıtım yapıldığı yönündeki görüşlere kararsız oldukları belirlenmiştir (Çizelge 1). Taşçıŏlu (2011) tarafından yapılan araştırmada, Batı Akdeniz Bölgesinde Kırsal Kalkınma Yatırımlarının Desteklenmesi Programından yararlanan üreticilere göre desteğin kullanımı ile ilgili en önemli ve katıldıkları düşünce destekleme programının devam etmesidir. Ayrıca üreticiler programın devam etmesi yanında parasal miktarın arttırılması görüşüne de katıldıklarını belirtmişlerdir. Çobanoğlu ve ark. (2014) tarafından yürütülen araştırmada ise, Antalya, Aydın, Bursa, Konya, Samsun ve Erzurum illerinde Kırsal Kalkınma Yatırımlarının Desteklenmesi Programı makine ekipman alımı desteğinden faydalanan üreticilerin hibe desteği ile alınan ekipmanın fiyatının piyasa fiyatına göre makul seviyede olduğu görüşüne katılmadıkları tespit edilmiştir. Araştırma sonuçları, Taşçığlu (2011) ve Çobanoğlu ve ark. (2014) araştırma sonuçlarıyla benzerlik göstermektedir.

Çizelge 1. Üreticilerin desteklemelerin başarısı ve amacına ulaşması yönündeki düşünceleri

\begin{tabular}{|c|c|c|c|c|c|c|c|}
\hline \multirow{2}{*}{$\begin{array}{l}\text { Üreticilerin desteklemelerin başarıs } \text { ve amacına } \\
\text { ulaşması yönündeki düşünceleri }\end{array}$} & \multicolumn{5}{|c|}{ Önem dereceleri } & \multirow{2}{*}{ Ort } & \multirow{2}{*}{$\begin{array}{c}\text { Std. } \\
\text { sapma }\end{array}$} \\
\hline & 1 & 2 & 3 & 4 & 5 & & \\
\hline Destek devam etmelidir. & 0 & 0 & 0 & 14 & 27 & 4,66 & 0,48 \\
\hline Destek konu itibariyle yaygınlaştırılmalıdır. & 0 & 0 & 0 & 18 & 23 & 4,56 & 0,50 \\
\hline Destek miktarı arttırılmalıdır. & 0 & 0 & 0 & 19 & 22 & 4,54 & 0,51 \\
\hline Çevremi destekten yararlanmaları için teşvik ederim. & 0 & 0 & 0 & 19 & 22 & 4,54 & 0,51 \\
\hline Destek bölge altyapısına katkı sağlamaktadır. & 1 & 0 & 1 & 24 & 15 & 4,27 & 0,74 \\
\hline $\begin{array}{l}\text { Destek bölgede ekonomik faaliyet çeşitliliğinin } \\
\text { artmasını sağlamıştır. }\end{array}$ & 1 & 2 & 2 & 18 & 18 & 4,22 & 0,94 \\
\hline $\begin{array}{l}\text { Destek ile ekipman almakla faydalı bir iş yaptığımı } \\
\text { düşünüyorum. }\end{array}$ & 1 & 1 & 4 & 18 & 17 & 4,20 & 0,90 \\
\hline Destek ile alınan ekipmanın kalitesi yeterli seviyededir. & 1 & 4 & 6 & 16 & 14 & 3,93 & 1,06 \\
\hline $\begin{array}{l}\text { Destek ile alınan ekipmanın satış sonrası servis } \\
\text { hizmetleri yeterli düzeydedir. }\end{array}$ & 2 & 3 & 7 & 16 & 13 & 3,85 & 1,11 \\
\hline Hibe ödemelerinde belirli bir düzen ve istikrar vardır. & 2 & 3 & 8 & 20 & 8 & 3,71 & 1,03 \\
\hline $\begin{array}{l}\text { Bakanlı̆̆ın belirlediği ekipmanın müracaat kriterlerinden } \\
\text { memnuniyet seviyesi iyi düzeydedir. }\end{array}$ & 3 & 5 & 6 & 15 & 12 & 3,68 & 1,23 \\
\hline $\begin{array}{l}\text { Destek ile alınan ekipmanın fiyatı, piyasa fiyatına göre } \\
\text { makul seviyededir. }\end{array}$ & 2 & 7 & 4 & 18 & 10 & 3,66 & 1,18 \\
\hline Destekte üretici ön plandadır. & 2 & 5 & 8 & 20 & 6 & 3,56 & 1,05 \\
\hline Destek için verilen yatırım süresi uygundur. & 5 & 4 & 9 & 20 & 3 & 3,29 & 1,15 \\
\hline Destekleme hakkında yeterince tanitım yapılmaktadır. & 7 & 4 & 8 & 19 & 3 & 3,17 & 1,24 \\
\hline
\end{tabular}

1. Kesinlikle katılmıyorum 2. Katılmıyorum 3. Kararsızım 4. Katılıyorum 5. Kesinlikle katılıyorum

Üreticilerin damla sulama desteklemesinin başarısı ve amacına ulaşması yönündeki düşünceleri ile ilgili faktör analizi sonuçları Çizelge 2'de verilmiştir. Faktör analizinin ilk aşamasında değişkenlerin faktör analizine uygunluğu belirlenmiştir. Üreticilerin damla sulama desteklemesinin başarısı ve amacına ulaşması ile ilgili faktörlerin Barlett Küresellik testi için hesaplanan ki kare değeri 462,06 ( $\mathrm{p}=0,000)$ olarak bulunmuş ve birim matris hipotezi reddedilmiştir $(\mathrm{p}<0,01)$. Kaiser-MeyerOlkin (KMO) oranı 0,638 olarak bulunmuş olup, bu değer, veri setinin faktör analizi için uygun olduğunu göstermektedir.

Başlangıçta yer alan 15 değişken kendi içerisinde ilişki derecelerine göre 4 faktöre indirgenmiştir. Bu çalışmada faktör analizi yönteminin uygulanabilirliğini test etmede ortaklık unsuru dikkate alınmıştır. Ortaklık unsuru değeri 0,50 'den yüksek olan değişkenler değerlendirmeye alınmıştır. Değişkenlerin tamamının ortaklık unsuru değeri 0,50 'den yüksek olup ortalama ortaklık unsurları 0,782'dir. Bu da kullanılan değişkenlerin faktör analizi için uygun olduğunu göstermektedir. Belirlenen 4 faktör ile toplam varyansın \%78,22'si açıklanmıştır. İlk faktör toplam varyansın $\% 26,57$ 'sini, ikinci faktör toplam varyansın $\% 22,43$ 'ünü, üçüncü faktör toplam varyansın $\% 17,50$ 'sini, dördüncü faktör toplam varyansın \%11,72'sini açıklamaktadır. Faktörlerin yorumlanabilmesi için faktör rotasyonu yapılmıştır.

F1 faktörünü oluşturan kriterler incelendiğinde bu kriterlerin üreticilerin ekipmanlardan memnuniyeti ile ilgili olduğu görülmektedir. Bu faktörü oluşturan kriterlerden "Bakanlığın belirlediği 
ekipmanın müracaat kriterlerinden memnuniyet seviyesi iyi düzeydedir" kriteri 0,928, "Destek ile alınan ekipmanın satış sonrası servis hizmetleri yeterli düzeydedir" kriteri 0,885 , "Destek ile alınan ekipmanın kalitesi yeterli seviyededir" kriteri 0,856, "Destek ile alınan ekipmanın fiyatı, piyasa fiyatına göre makul seviyededir" kriteri 0,837 ve "Destek ile ekipman almakla faydalı bir iş yaptığımı düşünüyorum" kriteri 0,781 faktör yüklerine sahipken, bütün kriterlerin ortalama faktör yükü 0,857'dir. Üreticilerin destek ile alınan ekipmanla ilgili yargılarını içeren kriterlerden oluştuğu için, bu faktör "Ekipmanlardan Memnuniyet" olarak isimlendirilmiştir.

F2 faktörünü oluşturan kriterler incelendiğinde bu kriterlerin desteğin etkinliğinin arttırılması ile ilgili olduğu görülmektedir. Bu faktörü oluşturan kriterler incelendiğinde, "Destek devam etmelidir" ve "Destek konu itibariyle yaygınlaştırılmalıdır" kriterleri 0,938 ve 0,908 faktör yükleri ile en yüksek faktör yüküne sahip değişkenler olurken bütün kriterlerin ortalama faktör yükü 0.888 olarak bulunmuştur. Üreticilerin desteğin etkinliğinin arttırılmasına yönelik yargılarını içerdiğinden dolayı, bu faktör "Desteğin Etkinliğinin Arttırılması" olarak isimlendirilmiştir.

F3 faktörü üzerine etkili olan "Destekleme hakkında yeterince tanıtım yapılmaktadır", "Destek için verilen yatırım süresi uygundur", "Hibe ödemelerinde belirli bir düzen ve istikrar vardır" ve "Destekte üretici ön plandadır" kriterlerinin ortalama faktör yükleri 0,790 olarak bulunmuştur. Desteğin uygulama aşamasındaki yargıları içeren kriterlerden oluştuğu için bu faktör "Destek Uygulama Aşamalarından Memnuniyet” olarak tanımlanmıştır.

Çizelge 2. Damla sulama desteklemesinin başarısı ve amacına ulaşması ile ilgili faktör analizi sonuçları

\begin{tabular}{|c|c|c|c|c|}
\hline Faktörler & F1 & F2 & F3 & $\mathrm{F} 4$ \\
\hline \multicolumn{5}{|l|}{ Ekipmanlardan Memnuniyet (F1) } \\
\hline $\begin{array}{l}\text { Bakanlığın belirlediği ekipmanın müracaat kriterlerinden } \\
\text { memnuniyet seviyesi iyi düzeydedir. }\end{array}$ & 0,928 & 0,032 & 0,125 & $-0,064$ \\
\hline $\begin{array}{l}\text { Destek ile alınan ekipmanın satı̧s sonrası servis hizmetleri yeterli } \\
\text { düzeydedir. }\end{array}$ & 0,885 & 0,026 & $-0,108$ & 0,043 \\
\hline Destek ile alınan ekipmanın kalitesi yeterli seviyededir. & 0,856 & 0,031 & $-0,166$ & 0,156 \\
\hline $\begin{array}{l}\text { Destek ile alınan ekipmanın fiyatı, piyasa fiyatına göre makul } \\
\text { seviyededir. }\end{array}$ & 0,837 & 0,078 & 0,130 & $-0,023$ \\
\hline $\begin{array}{l}\text { Destek ile ekipman almakla faydalı bir iş yaptığımı düşünüyorum. } \\
\text { Desteklemenin Etkinliğinin Arttırılması (F2) }\end{array}$ & 0,781 & 0,91 & $-0,013$ & 0,068 \\
\hline Destek devam etmelidir. & 0,080 & 0,938 & 0,053 & 0,088 \\
\hline Destek konu itibariyle yaygınlaştırılmalıdır. & 0,043 & 0,908 & 0,033 & 0,005 \\
\hline Çevremi destekten yararlanmaları için teşvik ederim. & 0,199 & 0,853 & 0,104 & $-0,059$ \\
\hline Destek miktarı arttırılmalıdır. & 0,039 & 0,853 & 0,073 & $-0,048$ \\
\hline \multicolumn{5}{|l|}{ Destek Uygulama Aşamalarından Memnuniyet (F3) } \\
\hline Destekleme hakkında yeterince tanıtım yapılmaktadır. & 0,146 & $-0,028$ & 0,867 & $-0,104$ \\
\hline Destek için verilen yatırım süresi uygundur. & 0,225 & $-0,049$ & 0,861 & $-0,033$ \\
\hline Hibe ödemelerinde belirli bir düzen ve istikrar vardır. & $-0,224$ & 0,270 & 0,796 & 0,002 \\
\hline Destekte üretici ön plandadır. & $-0,340$ & 0,165 & 0,637 & 0,201 \\
\hline \multicolumn{5}{|l|}{ Desteğin Bölgeye Katkısı (F4) } \\
\hline Destek bölgede ekonomik faaliyet çeşitliliğinin artmasını sağlamıștır. & 0,019 & $-0,078$ & $-0,030$ & 0,928 \\
\hline Destek bölge altyapısına katkı sağlamaktadır. & 0,096 & 0,053 & 0,024 & 0,892 \\
\hline Özdeğerler & 28,99 & 22,15 & 15,44 & 11,64 \\
\hline Açıklanan Varyans Oranları & 26,57 & 22,43 & 17,50 & 11,72 \\
\hline Varyansın Kümülatif Oranları & 26,57 & 49,00 & 66,50 & 78,2 \\
\hline Ortaklık Unsurları & \multicolumn{4}{|c|}{0,782} \\
\hline KMO İstatistiği & \multirow{2}{*}{\multicolumn{4}{|c|}{$\begin{aligned} & 0,638 \\
\text { Ki kare } & 462,06 \mathrm{p}=0,000\end{aligned}$}} \\
\hline Barlett Küresellik Testi & & & & \\
\hline
\end{tabular}

F4 faktörünü oluşturan "Destek bölgede ekonomik faaliyet çeşitliliğinin artmasını sağlamıştır $(0,928)$ " ve "Destek bölge altyapısına katkı sağlamaktadır $(0,892)$ " kriterlerinin incelenen işletmelerin desteğin bölgeye katkıları hakkındaki düşüncelerini temsil ettiği görülmektedir. Bu ölçütlerin ortalama faktör yükleri 0.91 olarak bulunmuştur. Bu faktörün "Desteğin Bölgeye Katkısı" olarak adlandırılması uygun görülmüştür (Çizelge 2). 
Damla sulama desteklemesinin başarısı ve amacına ulaşmasında etkili olan faktörler, elde edilen faktör skorları üzerinden k-ortalamalar kümesi yöntemi ile üç küme olarak analize tabi tutulmuştur. Birinci küme ana kitlenin \%48,78'ini, ikinci küme $\% 41,46$ 'sını, üçüncü küme ise \%9,6'sını oluşturmaktadır. Birinci kümede "Desteğin Bölgeye Katkısı", ikinci kümede "Desteklemenin Etkinliğinin Arttırılması" ve "Ekipmanlardan Memnuniyet", üçüncü kümede "Desteklemenin Etkinliğinin Arttırılması" en fazla önem verilen faktörler olarak belirlenmiştir (Çizelge 3).

Çizelge 3. Damla sulama desteklemesinin başarısı ve amacına ulaşması ile ilgili kümeleme analizi sonuçları

\begin{tabular}{lrrr}
\hline \multirow{2}{*}{ Ana Faktörler } & \multicolumn{3}{c}{ Kümeler } \\
\cline { 2 - 4 } & \multicolumn{1}{c}{1} & \multicolumn{1}{c}{3} \\
\hline Ekipmanlardan Memnuniyet (F1) & $-0,41316$ & 0,60145 & $-0,49035$ \\
Desteklemenin Etkinliğinin Arttırılması (F2) & $-0,77019$ & 0,66059 & 1,04343 \\
Destek Uygulama Aşamalarından Memnuniyet (F3) & $-0,11228$ & 0,13883 & $-0,28630$ \\
Desteğin Bölgeye Katkısı (F4) & 0,13426 & 0,35789 & $-2,19235$ \\
Gözlem sayı1 & 20 & 17 & 4 \\
Ana kitledeki oranı (\%) & 48,78 & 41,46 & 9,76 \\
\hline
\end{tabular}

\section{Üreticilerin proje hazırlama aşamasında karşılaş̧tıları problemler}

Damla sulama desteği alan üreticilere proje hazırlama aşamasında karşılaştıkları problemler Çizelge 4'te verilmiştir. Üreticilerin proje aşamasında karşılaştıkları sorunlarla ilgili olarak genelde kararsız oldukları, proje danışmanının yüksek ücret istemesi ve yeterli bilgilendirme yapmaması, proje sahibi ile yeterinde iletişim kuramama, başvuru sırasında teknik elemanın yeterli bilgi vermemesi, proje danışmanının yeterli bilgi birikimine sahip olmaması ve proje danışmanı bulmakta zorluk çekildiği yönündeki yargılara katılmadıkları belirlenmiştir. Altuntop (2014) tarafından yapılan çalışmada, Mersin ilinde makine ekipman alımlarının desteklemesi programından yararlanan üreticiler dosya hazırlama ve bürokratik işlemlerin çokluğunu öncelikli sorun olarak belirtmişlerdir.

Çizelge 4. Üreticilerin proje hazırlama aşamasında karşılaştıkları problemler

\begin{tabular}{|c|c|c|c|c|c|c|c|}
\hline \multirow{2}{*}{$\begin{array}{l}\text { Üreticilerin proje hazırlama aşamasında karşılaştıkları } \\
\text { problemler }\end{array}$} & \multicolumn{5}{|c|}{ Önem dereceleri } & \multirow{2}{*}{ Ort } & \multirow{2}{*}{$\begin{array}{c}\text { Std. } \\
\text { sapma }\end{array}$} \\
\hline & 1 & 2 & 3 & 4 & 5 & & \\
\hline $\begin{array}{l}\text { Proje başvuru, kabul ve uygulanma süreçlerinde } \\
\text { bürokratik işlemler yoğundur. }\end{array}$ & 5 & 5 & 4 & 18 & 9 & 3,51 & 1,31 \\
\hline $\begin{array}{l}\text { Dosya hazırlama maliyeti yüksektir (analiz ve testler } \\
\text { vb.) }\end{array}$ & 5 & 10 & 3 & 14 & 9 & 3,29 & 1,38 \\
\hline Projeyle ilgili bürokratik işlemlerin takibi zordur. & 7 & 7 & 4 & 14 & 9 & 3,27 & 1,43 \\
\hline Başvuru süresi kısadır. & 8 & 9 & 3 & 13 & 8 & 3,10 & 1,46 \\
\hline $\begin{array}{l}\text { Gerekli izin ve ruhsatların alınmasında zorluklarla } \\
\text { karşılaşıyorum. }\end{array}$ & 7 & 10 & 4 & 12 & 8 & 3,10 & 1,43 \\
\hline $\begin{array}{l}\text { Proje hazırlama dokümanları yeterli ve anlaşılabilir } \\
\text { değildir. }\end{array}$ & 8 & 10 & 5 & 12 & 6 & 2,95 & 1,40 \\
\hline Başvuru materyalleri yetersizdir. & 10 & 8 & 9 & 10 & 4 & 2,76 & 1,34 \\
\hline Proje danışmanı yüksek ücret istemektedir. & 14 & 13 & 4 & 7 & 3 & 2,32 & 1,31 \\
\hline Proje danışmanı yeterli bilgilendirme yapmamaktadır. & 16 & 11 & 4 & 8 & 2 & 2,24 & 1,30 \\
\hline Proje sahibi ile yeterince iletişim kuramiyorum. & 16 & 12 & 4 & 7 & 2 & 2,20 & 1,27 \\
\hline $\begin{array}{l}\text { Başvuru sırasında teknik eleman yeterli bilgi } \\
\text { vermemektedir. }\end{array}$ & 15 & 14 & 4 & 5 & 3 & 2,20 & 1,27 \\
\hline Proje danışmanı yeterli bilgi birikimine sahip değildir. & 17 & 12 & 4 & 6 & 2 & 2,12 & 1,25 \\
\hline Proje danışmanı bulmakta zorluk çekiyorum. & 15 & 16 & 3 & 6 & 1 & 2,07 & 1,13 \\
\hline
\end{tabular}

Çobanoğlu ve ark. (2014) tarafindan yapılan çalışmada, Konya ve Samsun ve Şanlıurfa illerinde üreticilerin proje danışmanı bulmada zorluk çekmedikleri belirlenmiştir. Bursa ve Erzurum illerinde üreticilerin başvuru süresi hakkında, Aydın, Bursa, Erzurum ve Şanlıurfa illerinde ise üreticilerin başvuru materyallerinin yeterliliği konusunda kararsız oldukları tespit edilmiştir. Elde edilen bu sonuçlar, araştırma sonucuyla benzerlik göstermektedir. 
Üreticilerin proje hazırlama aşamasında karşılaştıkları problemler ile ilgili faktör analizi sonuçları Çizelge 5'te verilmiştir. Üreticilerin proje hazırlama aşamasında karşılaştıkları problemler ile ilgili faktörlerin Barlett Küresellik testi için hesaplanan ki kare değeri 404,64 ( $\mathrm{p}=0,000)$ olarak bulunmuş ve birim matris hipotezi reddedilmiştir $(\mathrm{p}<0,01)$. Kaiser-Meyer-Olkin (KMO) oranı 0,80 olarak bulunmuş olup, bu değer veri setinin faktör analizi için uygun olduğunu göstermektedir.

Başlangıçta yer alan 13 değişken kendi içerisinde ilişki derecelerine göre 3 faktöre indirgenmiştir. Ortaklık unsuru değeri 0,50'den yüksek olan değişkenler değerlendirmeye alınmıştır. Değişkenlerin tamamının ortaklık unsuru değeri 0,50 'den yüksek olup ortalama ortaklık unsurları 0,754'tür. $\mathrm{Bu}$ da kullanılan değişkenlerin faktör analizi için uygun olduğunu göstermektedir. Belirlenen 3 faktör ile toplam varyansın \%75,42'si açıklanmıştır. İlk faktör toplam varyansın \%33,17'sini, ikinci faktör toplam varyansın \%25,44'ünü, üçüncü faktör toplam varyansın \%16,80'ini açıklamaktadır.

F1 faktörünü oluşturan kriterler incelendiğinde bu kriterlerin proje danışmanı ile ilgili olduğu görülmektedir. "Proje danışmanı yeterli bilgilendirme yapmamaktadır" kriteri 0,895, "Proje danışmanı yeterli bilgi birikimine sahip değildir" kriteri 0,895, "Proje sahibi ile yeterince iletişim kuramıyorum" kriteri 0,891, "Proje danışmanı bulmakta zorluk çekiyorum" kriteri 0,886 ve "Proje danışmanı yüksek ücret istemektedir" 0,756 faktör yüklerine sahipken, bütün kriterlerin ortalama faktör yükü $0, .865$ 'dir. Üreticilerin destekleme sırasında proje danışmanı ile yaşadıkları sorunlarla ilgili yargılarını içerdiğinden dolayı, bu faktör "Proje Danışmanı İle İlgili Sorunlar" olarak isimlendirilmiştir.

F2 faktörünü oluşturan kriterler incelendiğinde, "Proje başvuru, kabul ve uygulanma süreçlerinde bürokratik işlemler yoğundur" ve "Projeyle ilgili bürokratik işlemlerin takibi zordur" kriterleri 0,894 ve 0,886 faktör yükleri ile en yüksek faktör yüküne sahip değişkenler olurken bütün kriterlerin ortalama faktör yükü 0,747 olarak bulunmuştur. Üreticilerin bürokratik işlemlerle ilgili karşılaştıkları sorunlara yönelik yargılarını içerdiğinden dolayı, bu faktör "Bürokratik İşlemlerle İlgili Sorunlar" olarak isimlendirilmiştir.

Çizelge 5. Üreticilerin proje hazırlama aşamasında karşılaştıkları problemler ile ilgili faktör analizi sonuçları

\begin{tabular}{lrrc}
\hline Faktörler & F1 & F2 & F3 \\
Proje Danışmanı İle İlgili Sorunlar (F1) & & & \\
\hline Proje danışmanı yeterli bilgilendirme yapmamaktadır. & 0,895 & 0,219 & 0,196 \\
Proje danışmanı yeterli bilgi birikimine sahip değildir. & 0,895 & 0,133 & 0,183 \\
Proje sahibi ile yeterince iletişim kuramıyorum. & 0,891 & 0,184 & 0,175 \\
Proje danışmanı bulmakta zorluk çekiyorum. & 0,886 & 0,089 & 0,088 \\
Proje danışmanı yüksek ücret istemektedir. & 0,756 & 0,254 & 0,243 \\
Bürokratik İşlemlerle İlgili Sorunlar (F2) & & \\
Proje başvuru, kabul ve uygulanma süreçlerinde bürokratik işlemler yoğundur. & $-0,027$ & 0,894 & 0,179 \\
Projeyle ilgili bürokratik işlemlerin takibi zordur. & 0,200 & 0,886 & $-0,240$ \\
Gerekli izin ve ruhsatların alınmasında zorluklarla karşılaşıyorum. & 0,318 & 0,745 & 0,202 \\
Dosya hazırlama maliyeti yüksektir (analiz ve testler vb.) & 0,183 & 0,657 & 0,459 \\
Başvuru materyalleri yetersizdir. & 0,332 & 0,554 & 0,387 \\
Başvuru İşlemleri İle İlgili Sorunlar (F3) & & \\
Başvuru süresi kısadır. & 0,084 & 0,177 & 0,805 \\
Başvuru sırasında teknik eleman yeterli bilgi vermemektedir. & 0,339 & 0,008 & 0,791 \\
Proje hazırlama dokümanları yeterli ve anlaşılabilir değildir. & 0,392 & 0,476 & 0,501 \\
Özdeğerler & 49,22 & 16,07 & 10,12 \\
Açıklanan Varyans Oranları & 33,17 & 25,44 & 16,80 \\
Varyansın Kümülatif Oranları & 33,17 & 58,61 & 75,41 \\
Ortaklık Unsurları & & 0,754 & \\
KMO İstatistiği & & 0,802 & \\
Barlett Küresellik Testi & Ki kare $=404,64 \mathrm{p}=0,000$ \\
\hline
\end{tabular}

F3 faktörü üzerine etkili olan "Başvuru süresi kısadır", "Başvuru sırasında teknik eleman yeterli bilgi vermemektedir" ve "Proje hazırlama dokümanları yeterli ve anlaşılabilir değildir" kriterlerinin ortalama faktör yükleri 0,699 olarak bulunmuştur. Desteğin başvuru aşamasında 
karşılaştıkları sorunlara ilişkin yargıları içeren kriterlerden oluştuğu için bu faktör "Başvuru İşlemleri İle İlgili Sorunlar" olarak adlandırılmıştır (Çizelge 5).

Proje hazırlama aşamasında karşılaşılan problemlere yönelik belirlenen faktörler, elde edilen faktör skorları üzerinden k-ortalamalar kümesi yöntemi ile üç küme olarak analize tabi tutulmuştur. Birinci küme ana kitlenin \%31,71'ini, ikinci küme \%41,46'sın1, üçüncü küme \%26,83'ünü oluşturmaktadır. Birinci kümede "Proje Danışmanı İle İlgili Sorunlar", ikinci kümede "Başvuru İşlemleri İle İlgili Sorunlar" ve "Bürokratik İşlemlerle İlgili Sorunlar" en fazla önem verilen faktörler olarak belirlenmiştir (Çizelge 6).

Çizelge 6. Proje hazırlama aşamasında karşılaşılan problemler ile ilgili kümeleme analizi sonuçları

\begin{tabular}{lrrr}
\hline \multirow{2}{*}{ Ana Faktörler } & \multicolumn{3}{c}{ Kümeler } \\
\cline { 2 - 4 } & \multicolumn{1}{c}{2} & \multicolumn{2}{c}{3} \\
\hline Proje Danışmanı İle İlgili Sorunlar (F1) & $0,57784,14660$ \\
Bürokratik İşlemlerle İlgili Sorunlar (F2) & 0,39738 & $-0,34702$ & $-1,43005$ \\
Başvuru İşlemleri İle İlgili Sorunlar (F3) & $-0,71624$ & 0,62145 & -67939 \\
Gözlem sayısı & 13 & $-0,20775$ \\
Ana kitledeki oranı (\%) & 31,71 & 17 & 11 \\
\hline
\end{tabular}

\section{Üreticilerin desteklemenin yasal yapısı ile ilgili düşüncelerinin faktör analizi ile değerlendirilmesi}

Üreticilerin desteklemenin yasal yapısı ile ilgili önemli gördükleri ve katıldıkları düşünce proje hazırlama öncesinde il/ilçe müdürlüğü elemanları tarafından teknik destek verilmesi gerekmesidir. Bunun yanında, üreticilerin, uygulama projeleri ile ilgili yasal düzenleme yapılması ve desteklemenin veriliş şeklinde düzenleme yapılması gerektiği yönündeki düşüncelere de katıldıkları görülmektedir. Buna karşılık işletmeler, destek için çıkarılmış yasanın yeterli olma ve yasa hakkında yeterli bilgi sahibi olma durumuna karşı kararsız olduklarını ifade etmişlerdir (Çizelge 7). Taşçığlu (2011) tarafından yapılan çalışmada, üreticiler, istenen belgelerin fazla olmasının yanında bürokratik engellerin fazla olması ve desteklemenin veriliş şeklinde düzenlemenin yapılması konusuna da katılmaktadır. Üreticiler, destek programı için çıkarılmış yasanın yeterli olma durumuna karşı kararsız kalmışlardır. Araştırma sonuçları, Taşçığlu (2011) araştırma sonucuyla benzerlik göstermektedir.

Çizelge 7. Üreticilerin desteklemenin yasal yapısı ile ilgili düşünceleri

\begin{tabular}{|c|c|c|c|c|c|c|c|}
\hline \multirow{2}{*}{$\begin{array}{l}\text { Üreticilerin desteklemenin yasal yapısı ile ilgili } \\
\text { düşünceleri }\end{array}$} & \multicolumn{5}{|c|}{ Önem dereceleri } & \multirow{2}{*}{ Ort } & \multirow{2}{*}{$\begin{array}{l}\text { Std. } \\
\text { sapma }\end{array}$} \\
\hline & 1 & 2 & 3 & 4 & 5 & & \\
\hline $\begin{array}{l}\text { Proje hazırlama öncesinde il/ilçe müdürlüğü elemanları } \\
\text { teknik destek vermelidir. }\end{array}$ & 0 & 0 & 0 & 14 & 27 & 4,66 & 0,48 \\
\hline $\begin{array}{l}\text { Uygulama projeleri ile ilgili yasal düzenleme } \\
\text { yapılmalıdır. }\end{array}$ & 0 & 2 & 7 & 16 & 16 & 4,12 & 0,87 \\
\hline Desteklemenin veriliş şseklinde düzenleme yapılmalıdır. & 3 & 1 & 4 & 18 & 15 & 4,00 & 1,12 \\
\hline Çıkarılan yasanın tanıtımı yeterince yapılmamıştır. & 2 & 5 & 6 & 14 & 14 & 3,80 & 1,19 \\
\hline İstenen belgeler fazla. & 4 & 8 & 3 & 10 & 16 & 3,63 & 1,43 \\
\hline Bürokratik engeller fazla. & 5 & 4 & 8 & 12 & 12 & 3,54 & 1,34 \\
\hline Destek için çıkarılmış yasa yeterlidir. & 7 & 3 & 10 & 17 & 4 & 3,20 & 1,25 \\
\hline Yasa hakkında yeterli bilgiye sahibim. & 6 & 9 & 4 & 18 & 4 & 3,12 & 1,29 \\
\hline
\end{tabular}

$\begin{array}{lllll}\text { 1. Kesinlikle katılmıyorum } & \text { 2. Katılmıyorum } & \text { 3. Kararsızım } & \text { 4. Katılıyorum } & \text { 5. Kesinlikle katılıyorum }\end{array}$

Üreticilerin desteklemenin yasal yapısı yönündeki düşünceleri ile ilgili faktör analizi sonuçları Çizelge 8'de verilmiştir. Barlett Küresellik testi için hesaplanan ki kare değeri $116.68(\mathrm{p}=0,000)$ olarak bulunmuş ve birim matris hipotezi reddedilmiştir $(\mathrm{p}<0,01)$. Kaiser-Meyer-Olkin (KMO) oranı 0,59 olarak bulunmuş olup, bu değer veri setinin faktör analizi için uygun olduğunu göstermektedir.

Başlangıçta yer alan 8 değişken kendi içerisinde ilişki derecelerine göre 3 faktöre indirgenmiştir. Ortaklık unsuru değeri 0,40 'tan yüksek olan değişkenler değerlendirmeye alınmıştır. Değişkenlerin tamamının ortaklık unsuru değeri 0,40 'tan yüksek olup ortalama ortaklık unsurları 0,691'dir. $\mathrm{Bu}$ değer kullanılan değişkenlerin faktör analizi için uygun olduğunu göstermektedir. Belirlenen 3 faktör ile toplam varyansın \%69,12'si açıklanmıştır. İlk faktör toplam varyansın \%29,36'sın1, ikinci faktör toplam varyansın \%20,37'sini, üçüncü faktör toplam varyansın \%19,39'unu açıklamaktadır. 
F1 faktörünü oluşturan kriterler incelendiğinde "Bürokratik engeller fazla" ve "İstenen belgeler fazla" kriterlerinin faktör yükleri sırasılyla 0,946 ve 0,888 olarak bulunmuştur. Üreticilerin desteklemenin bürokratik işlemlerine yönelik yargılarını içerdiğinden dolayı, bu faktör "Bürokratik İşlemlerin Azaltılması" olarak isimlendirilmiştir.

F2 faktörünü oluşturan kriterler incelendiğinde "Uygulama projeleri ile ilgili yasal düzenleme yapılmalıdır" kriterinin faktör yükü 0.808 , "Proje hazırlama öncesinde il/ilçe müdürlügü elemanları teknik destek vermelidir" kriterinin faktör yükü 0,801 ve "Desteklemenin veriliş şeklinde düzenleme yapılmalıdır" kriterinin faktör yükü 0.488 olarak bulunmuştur. Proje ve destekleme ile ilgili yapılması gereken kriterleri içerdiği için bu faktörün "Düzenleme ve Teknik Destek" olarak adlandırılması uygun görülmüştür.

F3 faktörü üzerine etkili olan "Yasa hakkında yeterli bilgiye sahibim" kriterinin faktör yükü 0,821, "Destek için çıkarılmış yasa yeterlidir" kriterinin faktör yükü 0,652 olarak bulunmuştur. Destek için çıkarılmış yasanın yeterliliğine ilişkin yargıları içeren kriterlerden oluştuğu için bu faktör "Destekleme Yasası Hakkında Görüşler" olarak tanımlanmıştır.

Çizelge 8. Üreticilerin desteklemenin yasal yapısı yönündeki düşünceleri ile ilgili faktör analizi sonuçları

\begin{tabular}{|c|c|c|c|}
\hline Faktörler & F1 & F2 & F3 \\
\hline \multicolumn{4}{|l|}{ Bürokratik İşlemlerin Azaltılması (F1) } \\
\hline Bürokratik engeller fazla. & 0,946 & $-0,009$ & $-0,049$ \\
\hline İstenen belgeler fazla. & 0,888 & 0,222 & $-0,119$ \\
\hline \multicolumn{4}{|l|}{ Düzenleme ve Teknik Destek (F2) } \\
\hline Uygulama projeleri ile ilgili yasal düzenleme yapılmalıdır. & 0,442 & 0,808 & 0,059 \\
\hline $\begin{array}{l}\text { Proje hazırlama öncesinde il/ilçe müdürlüğü elemanları teknik destek } \\
\text { vermelidir. }\end{array}$ & $-0,239$ & 0,801 & $-0,330$ \\
\hline \multicolumn{4}{|l|}{ Destekleme Yasas1 Hakkında Görüşler (F3) } \\
\hline Yasa hakkında yeterli bilgiye sahibim. & 0,065 & 0,001 & 0,821 \\
\hline Destek için çıkarılmış yasa yeterlidir. & $-0,108$ & $-0,210$ & 0,652 \\
\hline Çıkarılan yasanın tanıtımı yeterince yapılmamıştır. & 0,447 & 0,040 & $-0,565$ \\
\hline Özdeğerler & 36,27 & 18,87 & 13,98 \\
\hline Açıklanan Varyans Oranları & 29,36 & 20,37 & 19,39 \\
\hline Varyansın Kümülatif Oranları & 29,36 & 49,73 & 69,12 \\
\hline Ortaklık Unsurları & & 0,691 & \\
\hline KMO İstatistiği & & 0,587 & \\
\hline Barlett Küresellik Testi & Ki kar & 116,68 & $=0,000$ \\
\hline
\end{tabular}

Proje hazırlama aşamasında karşılaşılan problemlere yönelik belirlenen faktörler, elde edilen faktör skorları üzerinden k-ortalamalar kümesi yöntemi ile üç küme olarak analize tabi tutulmuştur. Birinci küme ana kitlenin \%19,51'ini, ikinci küme \%63,41'ini, üçüncü küme \%17,07'sini oluşturmaktadır. İkinci kümede "Bürokratik İşlemlerin Azaltılması", üçüncü kümede "Düzenleme ve Teknik Destek" en fazla önem verilen faktörler olarak belirlenmiştir (Çizelge 9).

Çizelge 9. Üreticilerin desteklemenin yasal yapısı yönündeki düşünceleri ile ilgili kümeleme analizi sonuçları

\begin{tabular}{lrrr}
\hline \multirow{2}{*}{ Ana Faktörler } & \multicolumn{3}{c}{ Kümeler } \\
\cline { 2 - 4 } & \multicolumn{1}{c}{1} & \multicolumn{1}{c}{3} \\
\hline Bürokratik İşlemlerin Azaltıllmas1 (F1) & $-0,42154$ & 0,58214 & $-1,68049$ \\
Düzenleme ve Teknik Destek (F2) & $-1,39065$ & 0,24488 & 0,67978 \\
Destekleme Yasası Hakkında Görüşler (F3) & $-0,39157$ & 0,01601 & 0,38803 \\
Gözlem sayıs1 & 8 & 26 & 7 \\
Ana kitledeki oranı (\%) & 19,51 & 63,41 & 17,07 \\
\hline
\end{tabular}

\section{Sonuç ve Öneriler}

Üreticilerin damla sulama desteklemelerinin başarısı ve amacı ile ilgili düşünceleri ekipmanlar, desteklemenin etkinliği, destek uygulama aşamaları ve desteğin bölgeye katkısı olmak 
üzere dört başlık altında toplanmıştır. Üreticilerin destek ile alınan ekipmanın satış sonrası servis hizmetleri, kalitesi ve fiyatı ile ilgili genelde memnun oldukları belirlenmiştir. Damla sulama desteği üreticiler tarafindan memnuniyeti yüksek, devam etmesi istenen bir destekleme aracı olarak kabul edilmektedir. Üreticiler desteklemenin devam etmesi, desteğin konu itibariyle yaygınlaştırılması ve verilen destek miktarının arttırılması yönünde görüş bildirmişlerdir. Desteğin uygulanması aşamasında ise hibe ödemelerinin düzenli ödenmesi ve destek için verilen yatırım süresinin uygunluğu konusunda kararsız oldukları sonucuna ulaşılmıştır. Üreticiler desteğin bölge altyapısına ve ekonomik gelişimine olumlu yönde etki ettiği görüşündedirler.

Üreticilerin proje hazırlama aşamasındaki problemler proje danışmanı, bürokratik işlemler ve başvuru işlemleri olmak üzere üç başlık altında toplanmıştır. Üreticiler proje mühendisi ve proje danışmanı ile iletişimde sorun yaşamadıklarını ifade etmekle birlikte, daha fazla bilgilendirme talebinde bulunmaktadırlar. $\mathrm{Bu}$ doğrultuda, proje mühendisleri veya diğer teknik elemanların proje hazırlama dokümanları ve diğer destekleme konularında daha fazla bilgi vermesinin, hibe projelerinin daha sağlıklı uygulanmasına olumlu katkı sağlayacağı söylenebilir.

Üreticilerin desteklemenin yasal yapısı hakkındaki görüşleri bürokratik işlemlerin azaltılması, düzenleme ve teknik destek ve destekleme yasası olmak üzere üç başlık altında toplanmıştır. Bürokratik işlemlerin azaltılması ve/veya farklı sistemler geliştirerek bürokrasi yoğunluğunun üreticiye yansıması azaltılabilir ve böylece bürokratik yoğunluktan dolayı destek programına başvurmaktan vazgeçişlerin önüne geçilebilir. Destekler konusundaki yasal düzenlemelerin yeterliliği veya ilave düzenlemeler yapılması vb. görüşlerinde çok kesin ve kararlı değildirler. Bu verilere dayanarak, hibe desteklerinin sürdürülebilir olarak devam ettirilebilmesi için mevcut yasa ve düzenlemelerin yeterli olduğu belirtilebilir. Ancak, daha fazla yaygınlaştırılması ve destek miktarının arttırılması bu projelere olan talebi arttıracaktır. Bunun sonucunda da, şüphesiz, bölgede sulanabilir alanların artırılmasına ve su kaynaklarının daha etkin ve daha korumacı kullanılmasına katk1 sağlanmış olacaktır. Üreticilerin desteklemenin içeriği ve işleyişi konusunda üreticilerin yeterince ön bilgiye sahip olmadıkları anlaşılmaktadır. Bu bağlamda, yeterli bilgilendirmelerin yapılması amacıyla, ilgili kurumlar tarafından yürütülen çiftçi eğitim programları kapsamında bu konuya daha fazla yer verilmelidir

\section{Kaynaklar}

Akgül, A., Çevik, O., 2003. İstatistiksel Analiz Teknikleri. Emek Ofset, Ankara, 417s.

Alpar, R., 2011. Uygulamalı Çok Değişkenli İstatistiksel Yöntemler. Detay Yayıncılık, Ankara.

Altuntop, E., 2014. Kırsal Kalkınma Yatırımlarının Desteklenmesi Programı (KKYDP) Kapsamında Uygulanan Makine Ekipman Alımlarının Desteklenmesi Programı (MEADP) uygulama sonuçlarının değerlendirilmesi: Mersin ili örneği. Çukurova Üniversitesi Fen Bilimleri Enstitüsü Tarım Makinaları Anabilim Dalı, Doktora Tezi,118s.

Anonim, 2010. 2010 Yılında 2010 Proje Tanıtım Kitapçı̆̆ı. GTHB Teşkilatlanma ve Destekleme Genel Müdürlüğü, Ankara.

Ayran, Y., 2009. Sultanhisar yöresindeki çilek bahçelerinde kullanılan damla sulama sistemlerinin incelenmesi üzerine bir araştırma. Adnan Menderes Üniversitesi Fen Bilimleri Enstitüsü Tarımsal Yapılar ve Sulama Anabilim Dalı, Yüksek Lisans Tezi, 84s.

Beycan, H., 2009. Kırsal Kalkınma Yatırımlarının Desteklenmesi Programı ve bu çerçevede proje uygulama örneği. Dumlupınar Üniversitesi Sosyal Bilimler Enstitüsü İşletme Anabilim Dalı, Yüksek Lisans Tezi, $172 \mathrm{~s}$.

Çamoğlu G., Demirel, K., Genç, L., Eroğlu, İ., Boran, A., 2018. Damla sulama sistemlerinin CAD tabanlı bir program ile değerlendirilmesi: Kumkale, Çanakkale örneği. ÇOMÜ Zir. Fak. Derg. 6(1): 61-70.

Çobanoğlu, F., Yılmaz, H.ì., Tunalığlu, R., Bozkıran, S., Nalbantoğlu, A., Yıldız, H., 2014. Kırsal Kalkınma Yatırımlarını Destekleme Programının Etkisinin Değerlendirilmesi: Sorunlar ve olası çözüm önerileri. TAGEM-14/AR-GE/52. Yayın No: 275, ISBN: 978-605-9175-60-9.

Demirbük, M., 2013. Kırsal Kalkınma Yatırımlarının Desteklenmesi Programının Değerlendirilmesi: Sivas ili örneği. Gaziosmanpaşa Üniversitesi Fen Bilimleri Enstitüsü Tarım Ekonomisi Anabilim Dalı, Yüksek Lisans Tezi, $99 \mathrm{~s}$.

Demircioğlu, M., Çakmak, B., 2016. Ziraat Bankasının basınçlı sulama destek sisteminin değerlendirilmesi. Gaziosmanpaşa Üniversitesi Ziraat Fakültesi Dergisi. 33(3): 181-188.

Frandsen, S.E., Gersfelt, B., Jensen, H.G., 2002. Decoupling support in agriculture impacts of redesigning. European Agricultural Support Danish Research Institute of Food Economics (FOI). 
ÇOMÜ Zir. Fak. Derg. (COMU J. Agric. Fac.)

2019: 7 (1): 57-67

ISSN: 2147-8384 / e-ISSN: 2564-6826

doi: $10.33202 /$ comuagri.548920

Goeb, J.C., 2011. Impacts of government maize supports on smallholder cotton production in Zambia. Michigan State University, Agricultural, Food and Resource Economics Department, Michigan, a Thesis Master of Science.

Gürkan, M., 2012. Türkiye'de uygulanan tarımsal desteklerin üretici açısından değerlendirilmesi (Kahramanmaraş ili örneği). Gaziosmanpaşa Üniversitesi Fen Bilimleri Enstitüsü Tarım Ekonomisi Anabilim Dalı, Yüksek Lisans Tezi, 86s.

Hair, J.F., Anderson, R.E., Tahtam, R.L., Black, W.C., 1998. Multivariate Data Analysis, 374.

Kalaycı, Ş., 2009. SPSS Uygulamalı Çok Değişkenli İstatistik Teknikleri. Asil Yayın Dağıtım Ltd. Şti. 4. Baskı.

Kleimbaum, D.G., Lawrence, L.K., Keith, E.M., 1998. Applied regression analysis and other multivariable methods, Duxbury Press.

Mucuk, İ., 1978. İşletmelerde modern bir araştırma tekniği: faktör analizi, Yayınlanmamış Doçentlik Tezi.

Sharma, S., 1996. Applied multivariate techniques, John Wiley \& Sons Inc., New York.

Şahin, A., 2008. Avrupa Birliği'nde tek çiftlik ödeme yöntemi ve Türkiye’nin uyumu. T.C. Tarım ve Köyişleri Bakanlığg, Uzmanlık Tezi, Ankara.

Taşçığlu, Y., 2011. Kırsal Kalkınma Yatırımlarının Desteklenmesi Programının sosyal ve ekonomik yönden değerlendirilmesi: Batı Akdeniz Bölgesi örneği. Akdeniz Üniversitesi Fen Bilimleri Enstitüsü Tarım Ekonomisi Anabilim Dalı, Doktora Tezi, 208s.

TCRG., 2015. 31.12.2014 tarih, 2014/45 Karar No'lu Ulusal Kırsal Kalkınma Stratejisi (20142020). Yüksek Planlama Kurul Kararı. 21 Şubat 2015 tarih, 29274 sayılı Türkiye Cumhuriyeti Resmi Gazetesi. 